\title{
Environmental Impact of an Iberian Golf Course: The Case Study of Guadiana Golf in Badajoz, Spain
}

\author{
RUI ALEXANDRE CASTANHO \\ Faculty of Applied Sciences, WSB University \\ 41-300 Dabrowa Górnicza \\ POLAND \\ and \\ College of Business and Economics, University of Johannesburg \\ PO Box 524, Auckland Park \\ SOUTH AFRICA \\ JACINTO GARRIDO VELARDE \\ University Research Institute for Sustainable \\ Territorial Development (INTERRA), \\ University of Extremadura, SPAIN \\ and \\ Department of Social Sciences, Languages and Literatures \\ University of Extremadura \\ Elvas Avenue, no number, Badajoz, 06006 \\ SPAIN \\ LUÍS LOURES \\ Polythecnic Institute of Portalegre - IPP \\ 7300-110 Portalegre \\ PORTUGAL
}

\begin{abstract}
The golf courses are not isolated areas in the territory where they are located; instead, these elements are an integral part of the surrounding ecosystem. The golf courses are components of the landscape and, in addition to all the benefits of functional, visual, and economical that could bring to the region, they may also, if their management is correct, improve the quality of the environment.

This article, through a Case Study Research Method (CSR), applied to a Golf Course located in the Spanish city of Badajoz, will expose an Environmental Assessment Proposal as well as monitoring and mitigation measures regarding the major impacts produced by this Golf Course.

Throughout this study, it is possible to realize, once more, that the process of Environmental Impact Assessment and Environmental Impact Studies are the support base so that there is success in the design of sustainable Golf course. Moreover, we should consider the measures to mitigate the negative impacts and maximize the positive impacts and develop methods to conduct constant monitoring of these projects' typologies.
\end{abstract}

Key-Words: Environmental Impact Assessment (EIA), Golf Courses, Monitoring and Mitigation Measures, Territorial Management.

Received: January 30, 2021. Revised: June 20, 2021. Accepted: June 28, 2021. Published: July 6, 2021.

\section{An Introductory Framework}

The Environmental Impact Assessment (EIA) consists of determining the potential environmental, social and public health effects of a given project.
The EIA tries to assess the physical, biological, and socio-economic impacts to allow decisions to be carried out logically and rationally [1]. Attempts can also be made to mitigate possible adverse effects by identifying potential sites or alternative processes. 
However, there is not, nor can there be, a single and universal definition for the concept of EIA [2].

According to Clark [3], since the sixties, there has been a growing awareness of environmental issues, namely in interactions between development actions and their consequences for the environment. In developed countries, this problem has led public opinion to demand that ecological factors be explicitly considered in the decision-making process. In developing countries, a similar process began to show in the early 1990s, where the process is mainly led by government decision-making centers, with little involvement from the interested population.

However, in the 1960s, attempts were made to evaluate projects, which turned out to be unreliable and limited tools for preparing Technical Feasibility Studies and Cost-Benefit Analysis (CBA). CBA was developed as a method to express the impact of resource costs, assessed in monetary terms. As an example, the case of large-scale projects such as: The London Third Airport Proposal, and the Aswan Dam, which were evaluated using CBA techniques, causing widespread concern in the population, given that the gaps in the CBA were evident, namely in terms of assigning values real monetary values to environmental heritage, to which it is not possible to attribute a financial cost $[3,4]$.

According to Clark [3] and Partidário \& Jesus [1], EIA was initially conceived as an instrument designed to comply with legal requirements. Its beginnings date back to the 1970s when in the USA, the first EIA system was formally approved by the National Environmental Policy Act - NEPA. In both developed and developing countries, environmental assessment is currently an evolutionary, continuous, and gradual process that contributes to developing ecological planning and management strategies to achieve sustainable development [5-10].

The EIA process applied to Golf Courses arises to the extent that these areas (Golf Courses and Tourist Villages inherent to the Courses) intersect with ecological and environmental components sensitive to impacts, namely: i) water needs and water resources as irrigation network and other general infrastructures; ii) drainage network for game areas; iii) domestic wastewater drainage and treatment; iv) drinking water supply network; v) other infrastructures inherent to water Resources; vi) Landscape framework; and, vii) Security [11,12]. When EIA is applied to golf courses, the process must cover 3 phases: i) construction; ii) exploration; and iii)deactivation [1-4].

Contextually, this paper intends to develop a an Environmental Assessment Proposal (EAP) as well as monitoring and mitigation measures regarding the major impacts produced by this Golf Course.

Thereby, through a Case Study Research Method (CSR), applied to a Golf Course located in the Spanish city of Badajoz, an EAP its monitoring and mitigation directions about the main impacts produced by this project will be exposed and detailed.

\section{Methodology}

Considering the study intention, multiple techniques were required, as direct and indirect analysis methodologies - i.e., case study selection, site analysis, design and implementation of questionnaires and interviews with the main actors, among several other direct and indirect methods.

Thus, the methodological structure was composed of four main stages: (i) problem formulation; (ii) data collection through the analysis of the thematic literature and technical reports; (iii) case study visits and analysis; (iv) interpretation of the collected results; and (v) discussion, main conclusions, and recommendations.

\subsection{A brief description of the case study}

The Guadiana Golf course, located in Badajoz, was designed by Daniel Calero and José Maria Cañizares, in 1993, with 60 ha. The Golf Course is $6 \mathrm{~km}$ away from Badajoz and 10 minutes away from Portugal's border, between the Spanish capital (Madrid at 393 $\mathrm{km}$ ) and the Portuguese capital (Lisbon at $225 \mathrm{~km}$ ). The Guadiana Golf complex has an 18-hole course (18 greens), a training course, two putting greens, chipping green and training bunkers, a pro shop, and a clubhouse (Table 1 and Figure 1). The Club also has a cafeteria, restaurant, meeting rooms, billiard room, swimming pools, paddle tennis, tennis, squash, and gym.

\begin{tabular}{|c|c|c|c|c|c|}
\hline $\begin{array}{c}\text { Course } \\
\text { Areas }\end{array}$ & Greens & Tees & Fairways & Roughs & Bunkers \\
\hline $\begin{array}{c}\text { Surface } \\
\text { or units }\end{array}$ & 1,5 ha & 1 ha & 20 ha & 30 ha & 56 \\
\hline
\end{tabular}

Table 1: Major features of Guadiana Golf Course. 


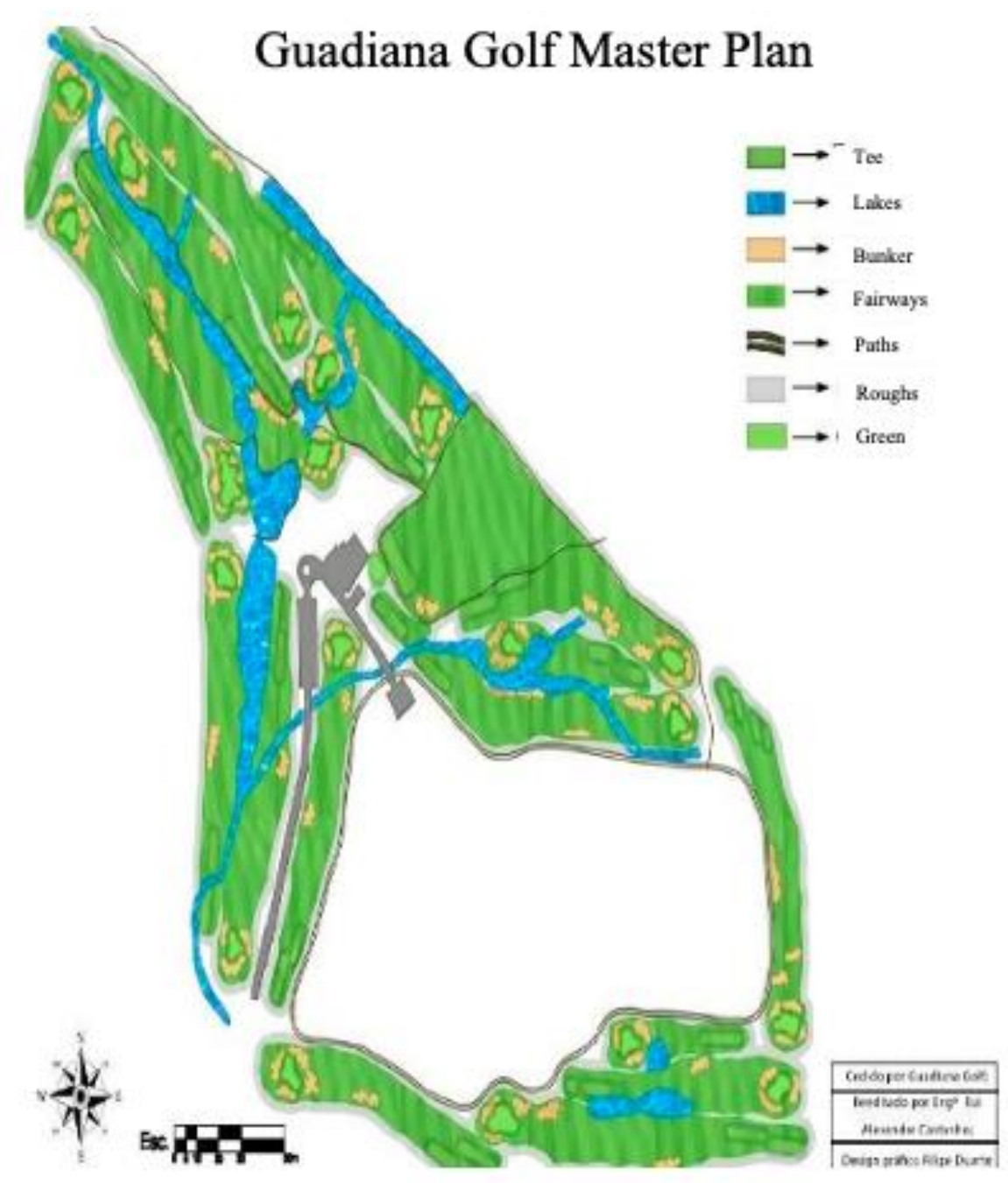

Figure 1: Master Plan of Guadiana Golf Course (adapted from [4]).

\begin{tabular}{|l|l|}
\hline $\begin{array}{l}\text { Environmental } \\
\text { descriptors }\end{array}$ & \multicolumn{1}{c|}{ Fundamental aspects to be considered } \\
\hline Climate & $\begin{array}{l}\text { - Climatic characterization (thermal amplitudes, rainy and dry periods, prevailing winds, } \\
\text { etc.) }\end{array}$ \\
\hline $\begin{array}{l}\text { Geomorphology } \\
\text { and geology }\end{array}$ & - The nearest weather stations. \\
\hline $\begin{array}{l}\text { Seismicity and } \\
\text { tectonics }\end{array}$ & $\begin{array}{l}\text { - Characterization of tectonic plates. } \\
\text { - Seismic Activity. }\end{array}$ \\
\hline $\begin{array}{l}\text { Soils and land- } \\
\text { use }\end{array}$ & $\begin{array}{l}\text { - Chear zones; } \\
\text { - Capacterization of the soils of the region. }\end{array}$ \\
\hline
\end{tabular}




\begin{tabular}{|c|c|}
\hline $\begin{array}{l}\text { Water } \\
\text { resources }\end{array}$ & $\begin{array}{l}\text { - Characterization of the hydrographic basin and sub-basins where the area affected by the } \\
\text { project (temporary watercourses, directions of runoff, the existence of dams, ponds, ponds, } \\
\text { and reservoirs, etc.). } \\
\text { - Characterization of the source of water for irrigation. } \\
\text { - Flood areas. } \\
\text { - Interferences in the Water Domain. }\end{array}$ \\
\hline Ecology & $\begin{array}{l}\text { - Identification and characterization of genetic resources, species and habitats, and ecosystem } \\
\text { services. } \\
\text { - Flora characterization. } \\
\text { - Fauna characterization. } \\
\text { - Protected areas. }\end{array}$ \\
\hline Landscape & $\begin{array}{l}\text { - Sign and characterization of the landscape units. } \\
\text { - Visual analysis. }\end{array}$ \\
\hline Heritage & $\begin{array}{l}\text { - Identification, characterization, and evaluation of values of interest for heritage (i.e., } \\
\text { architectural and archaeological). }\end{array}$ \\
\hline Socio-economy & $\begin{array}{l}\text { - Characterization of employment sectors. } \\
\text { - Main economic activities and contribution to the GDP. } \\
\text { - Municipal finance. } \\
\text { - Social equipment. }\end{array}$ \\
\hline $\begin{array}{l}\text { Spatial } \\
\text { planning }\end{array}$ & $\begin{array}{l}\text { - Description of all Territorial Management Tools (TMT), easements and restrictions of } \\
\text { public utility in force for the intervention area; framing of the project in the TMTs, } \\
\text { administrative easements, and restrictions of public utility in force - including conclusive } \\
\text { assessment as to their compatibility among them; also, identifying the applicable regulatory } \\
\text { provisions that supported the conclusions of the analysis. } \\
\text { - Extracts of the Planning / Zoning / Implementation plants of the various IGTs, } \\
\text { administrative easements, and restrictions of public utility in force for the intervention area, } \\
\text { including a surrounding area considered adequate according to the project under analysis. } \\
\text { - Extract from the Ecologic National Reserve (REN) Letter by the typology of areas listed in } \\
\text { the DL no 93/90, of } 19 \text { March (1990), in the wording given by DL no 180/06, of } 6 \\
\text { September (2006), published for the intervention area and a surrounding area considered } \\
\text { adequate depending on the project under analysis. } \\
\text { - In case of incompatibility of the project with the current IGT, detailed justification for not } \\
\text { opting for predicted locations and/or compatible with the current TMT. } \\
\text { - In case of incompatibility of the project with the current TMT, justification that allows } \\
\text { proving that the ordering/development models established in them are not questioned. } \\
\text { - In case of location in an area integrated into REN, proof of the absence of viable } \\
\text { alternatives in areas not integrated into REN for each of the project's different components. } \\
\text { - In the case of projects related to the mobilization and extraction of aggregates in the beds of } \\
\text { watercourses, an extract from the specific plan for the management of aggregates' extraction } \\
\text { in the water domain is integrated. If the project does not fit into the implementation of uses } \\
\text { of the water domain, justification is intended to improve the watercourse's working } \\
\text { conditions. } \\
\text { - A document that demonstrates the municipal interest of the project. } \\
\text { - In the case of opening of paths, topographic survey corresponding to the current situation of } \\
\text { the land and implantation plan with the final modeling of the land. }\end{array}$ \\
\hline
\end{tabular}

Table 2: Analyzed descriptors.

\begin{tabular}{|l|c|}
\hline \multicolumn{1}{|c|}{ Environmental descriptors } & Activities and potential impacts: Exploration phase \\
\hline Climate & $\begin{array}{l}\text { Golf Course Maintenance } \\
\text { - Higher water consumption due to climate in the process of irrigation } \\
\text { of plant material. }\end{array}$ \\
\hline
\end{tabular}




\begin{tabular}{|c|c|}
\hline Geomorphology and geology & $\begin{array}{l}\text { Golf Course Maintenance } \\
\text { - Changes in soil morphology due to specific golf course maintenance } \\
\text { processes. }\end{array}$ \\
\hline Soils and land-use & $\begin{array}{l}\text { Use of Vehicles (players, spectators, maintenance staff, etc.) and Machinery for } \\
\text { Vegetation Management and Vegetation Cover } \\
\text { - Compaction. } \\
\text { - Erosion. } \\
\text { - Excess Load Capacity. } \\
\text { - Soil contamination by Oil Spill, Fuels and Herbicides. } \\
\text { - Phytopharmaceutical Products. } \\
\text { - Soil Contamination by Other Wastes. } \\
\text { - Increase or Decrease of Organic and Nutrient Content. }\end{array}$ \\
\hline Water resources & 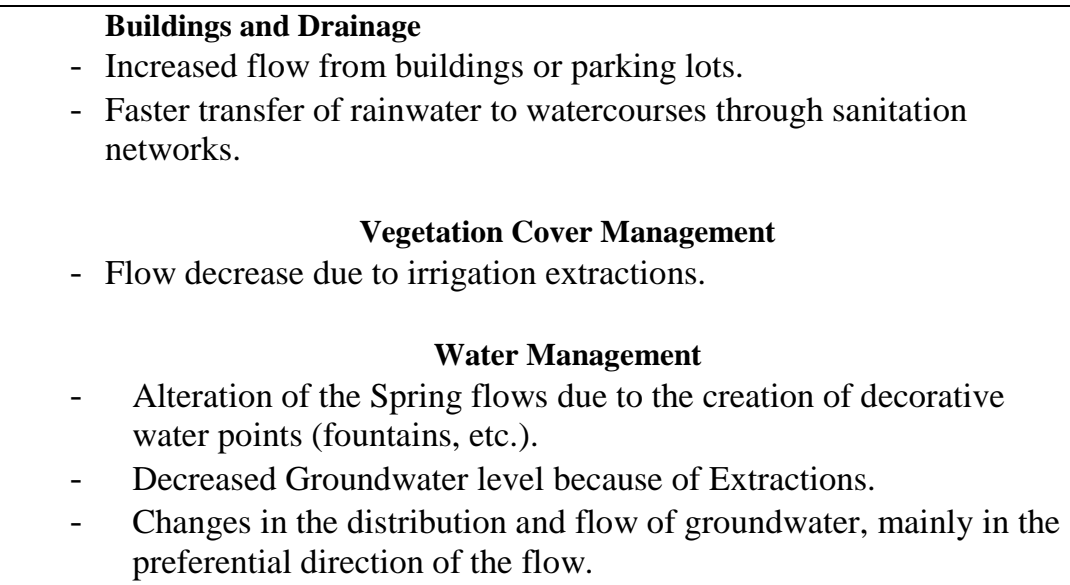 \\
\hline Ecology & $\begin{array}{l}\text { Vegetation Cover Management } \\
\text { - Direct and Indirect Effects of Pesticides, Oils and Other Substances } \\
\text { entering the Aquatic Environment. } \\
\text { - Increased risk of Algae blooming due to contamination by } \\
\text { watercourse fertilizers. } \\
\text { - Alteration of terrestrial habitats. } \\
\text { - Impacts on Terrestrial Fauna and Flora due to the use of } \\
\text { Phytopharmaceuticals. } \\
\text { - Alteration of biodiversity resulting from Golf Course management } \\
\text { - } \text { practices. } \\
\text { Opportunities for the creation of new habitats. } \\
\text { - Indirect effects on aquatic fauna and flora due to changes in course } \\
\text { to hydrology and morphology of watercourses. } \\
\text { - Opportunities for the creation of new habitats. }\end{array}$ \\
\hline
\end{tabular}




\begin{tabular}{|c|c|}
\hline Landscape & $\begin{array}{l}\text { Golf Course and Associated Complex } \\
\text { - Alteration of landscape aesthetics. } \\
\text { - Visual Impact of the Golf Course and Associated Infrastructures. }\end{array}$ \\
\hline Socio-economy & $\begin{array}{l}\text { Presence Golf of the Course } \\
-\quad \text { Increased employment opportunity. } \\
-\quad \text { Investment in Qualified Local Manpower. } \\
-\quad \text { Diversification of the Local Economic Fabric. } \\
-\quad \text { Increase in the Soil Value. } \\
-\quad \text { Secondary development consubstantiated by low density Housing. } \\
\text { - } \quad \text { Diversification of the Tourist Offer. } \\
\text { Golf Course Maintenance } \\
\text { Vegetation Cover Management } \\
\text { - } \quad \text { Risk of harm to humans through the use of plant protection } \\
\text { products. } \\
\text { Risk of injury to players and spectators from sports (Golf). }\end{array}$ \\
\hline Spatial planning & $\begin{array}{l}\text { Increase of the land value inherent to the area of the Guadiana Golf } \\
\text { Complex and its surroundings. }\end{array}$ \\
\hline
\end{tabular}

Table 3: Summary of the main descriptors and potential impacts in the exploration phase of Campo Guadiana Golf.

\begin{tabular}{|c|c|}
\hline Environmental descriptors & Activities and potential impacts: Exploration phase \\
\hline Climate & $\begin{array}{l}\text { Changes in soil temperature (watering is interrupted, as well as lawn } \\
\text { maintenance operations) }\end{array}$ \\
\hline Geomorphology and geology & - Not applicable in the deactivation phase. \\
\hline Soils and land-use & $\begin{array}{l}\text { Vegetation Cover Management } \\
\text { - Excess storage of organic matter in the soil, due to interruption of } \\
\text { maintenance operations. } \\
\text { - Long-term decontamination of soils due to the non-use of } \\
\text { phytopharmaceuticals. } \\
\text { - Nutritional shock in the soil due to the stop of fertilization programs. }\end{array}$ \\
\hline Water resources & $\begin{array}{l}\text { Buildings and Drainage } \\
\text { - } \quad \begin{array}{l}\text { Interruption of wastewater runoff from buildings. } \\
\text { - }\end{array} \\
\text { Decreased speed of rainwater transfer to water courses. } \\
\text { - } \quad \begin{array}{l}\text { Fegetation Cover Management } \\
\text { Wlow regularization due to irrigation stoppage. } \\
\text { Water Management }\end{array} \\
\text { - } \quad \begin{array}{l}\text { Flow regulation due to the cessation of irrigation of decorative water } \\
\text { points. }\end{array} \\
\text { Increase in water table level due to interruption of water extraction. }\end{array}$ \\
\hline
\end{tabular}




\begin{tabular}{|c|c|}
\hline & $\begin{array}{l}\text { Regularization of distribution and flow of groundwater, namely with } \\
\text { regard to the preferential direction of the natural flow of water. }\end{array}$ \\
\hline Ecology & $\begin{array}{l}\text { Vegetation Cover Management } \\
\text { - Reduction in the risk of algae appearing in artificial water points } \\
\text { (lakes), due to the cessation of the use of fertilizers and pesticides. } \\
\text { - Medium- to long-term recovery of native habitats. } \\
\text { - Medium - long term recovery of native fauna and flora. } \\
\text { Documents and Procedural Tools } \\
\text { - There is not a Deactivation Plan Closure; Intervention Area Recovery } \\
\text { Plan for this Golf Course. }\end{array}$ \\
\hline Landscape & $\begin{array}{l}\text { Landscape and Surroundings } \\
\text { - Medium - long term recovery of the native landscape. } \\
\text { Documents and Procedural Tools } \\
\text { - There is not a Deactivation Plan Closure; Intervention Area Recovery } \\
\text { Plan for this Golf Course. }\end{array}$ \\
\hline Socio-economy & $\begin{array}{ll} & \text { Golf Course Deactivation } \\
- & \text { Decrease in jobs in the Region. } \\
- & \text { Decrease in investment in the Region. } \\
- & \text { Decrease of the land value. } \\
\text { - } & \text { Decreased tourist offer in the Region. } \\
\text { Vegetation Cover Management } \\
\text { - } \quad \text { Reduction of risks to the population due to the stop use of plant } \\
\quad \text { protection products. }\end{array}$ \\
\hline Spatial planning & $\begin{array}{l}\text { Decrease of the land value inherent to the area of the Guadiana Golf } \\
\text { Complex and its surroundings. }\end{array}$ \\
\hline
\end{tabular}

Table 4: Summary of the main descriptors and potential impacts in the deactivation phase of Campo Guadiana Golf.

\subsection{The selected and analyzed descriptors}

Bearing in mind that the definition of an EIA is an initial step for identifying the analysis domains to be developed and, above all, of their deepening degree, depending on the type of impacts induced by the Guadiana Golf. Moreover, we should consider the sensitivity of the environment where it is inserted [10].

In this sense, the following ten descriptors were considered: (i) climate; (ii) geomorphology and geology; (iii) seismicity and tectonics; (iv) soils and land-use; (v) water resources; (vi) ecology; (vii) landscape; (vii) heritage; (viii) socio-economy; (ix) 
and spatial planning. Moreover, and based on the thematic literature the fundamental aspects were considered for each one of the selected environmental descriptors (Table 2). These descriptors were selected based on previous studies (see: $[1,2-11,12])$.

\section{Study Results}

Throughout this section, the main EIA descriptors applied to the case study were described and analyzed. Therefore, the impacts related to the project's exploration (Table 3) and deactivation (Table 4) phases will be summarized.

From the ten descriptors initially consider, we only used eight once these were the ones that best apply for the proper analysis of this particular case study.

\section{Discussion and Conclusions}

Environmental monitoring is a concept defined in the current legislative framework on EIA, Decree-Law no. 69/2002, of 3 May, amended and republished by Decree-Law no197/2005, of 8 November $[1,4]$.

According to these diplomas, environmental monitoring is: "(...) a process of systematic observation and data collection on the state of the environment or the environmental effects of a given project and periodic description of these effects through reports of the proponent's responsibility, in order to allow the assessment of the effectiveness of the measures provided for in the EIA procedure to avoid, minimize or compensate for the significant environmental impacts arising from the execution of the respective project."

The Environmental Monitoring Plan was developed and sustained on a methodological basis aiming at:

(i) Validate the assumptions and results of the environmental impact assessment;

(ii) Detect in a convenient method the existence of negative impacts that have not been predicted;

(iii) Assess the effectiveness of the proposed measures to prevent or mitigate negative impacts and enhance the positive ones;

(iv) Identify the need to implement additional mitigation measures and obtain the necessary elements for a correct assessment of the problem and the appropriate corrective measures.

The monitoring measures presented for the Guadiana Golf course include and provide constant and/or periodic measurement plans for the following environmental elements: edaphoclimatic factors, water resources, fauna and flora, waste, air quality, and noise environment, among several others.

Therefore, the monitoring and mitigation guidelines about the main impacts produced by this project will be exposed and detailed in the following:

- For good practice and environmental management, a Soil Fertilization Plan should be implemented, with annual regularity, aiming at collecting soil analyzes and data related to the frequency of precipitation as well as tests and analyzes of irrigation allocations;

- Also, concerning soils, salinization is a critical aspect to monitor. Its monitoring is facilitated by the fact that the harmful sodium salts (Na) increase the solutes' conductivity, being able to deduce its concentration from that same conductivity. Monitoring of soil salinity must be compiled annually [4,12];

- Concerning artificial water points (lakes, ponds, etc.), these must be monitored using chemical analysis of the water every six months, evaluating the parameters stipulated by the Municipality of Badajoz for Water Quality;

- Since the study area is part of the Guadiana River Hydraulic Basin and directly benefits from one of its "Arroyo de Los Rostros" branches (small river), it is promptly necessary to carry out analyzes of this watercourse to avoid any outbreak of pollution from the management of the golf course;

- A Monitoring Plan for fauna species in the study area is foreseen by collecting semiannual or annual data on the number of exemplars existing in the study area;

- About avifauna, a Monitoring Plan must be drawn up for a minimum period of three years, during the breeding season and in the winter season. In the case of reptiles and amphibians, systematic surveys should be carried out on the ground to know the evolution of the specific composition of the respective communities $[4,12]$; 
The management of plant material should be effective as well as its corresponding monitoring; thus, avoiding the risk of loss of fauna species with high patrimonial and/or regional value. The study will provide information on habitats' surrounding quality and alert to specific management problems $[2-4,11]$;

- Generally, the standard measure to be adopted in flora and fauna is the correct implementation of an Environmental Management System, in which one of the pillars is the preservation of nature [13-24];

- As far as waste management is concerned, a Waste Monitoring Plan should be drawn up that contemplates the quantification of waste and its classification according to the EWL (European Waste List) code, hazard, temporary storage conditions, and final destination. The compliance with legislation regarding authorizations, transport guides, and legal declarations of the waste produced [11,12];

- A Noise Monitoring Plan should be taken into account to analyze the noise levels generated in the golf course maintenance operations and the road traffic inherent to it;

- A Monitoring Plan for the Socio-Economic Management of the Golf Course should be carried out. This descriptor is one of the most important in what concerns the Guadiana Golf project;

- In the authors' opinion, for this case study, it is not justified to define a monitoring plan for the following descriptors: Heritage, Seismicity and Tectonics, and Territorial Planning.

\section{Study Limitations and Future Research Lines}

Considering that the construction phase had already been completed by this study's time, we only focused on the exploration and deactivation phases. However, this phase's principal and predictable impacts have been felted in the study area and its surroundings. Therefore, if we focus on the construction phase, the impacts are supported by similar case studies, namely EIA referring to golf courses in the Region of Algarve and Alto Alentejo. In fact, the impacts contained in these studies have been described as very similar to the ones that occurred in the construction phase of the Guadiana Golf course.

Although this research provides us some insights into the environmental impact of an Iberian golf course project, as is the case of Guadiana Golf in Badajoz, we would intercross more variables and significant findings if more studies were carried out to developing in this thematic domain.

Moreover, considering the simplicity of the used methodology, we believe that the methods could be easily replicated in other case studies. Therefore, it will be possible to create a broader debate on this specific topic by comparing different case studies.

\section{Contribution of individual authors to the creation of a scientific article (ghostwriting policy)}

Author Contributions: All the authors contributed equally to the development of the present paper. All phases of the paper development have been proper discussed and worked on by the authors. All authors have read and agreed to the published version of the manuscript.

\section{Sources of funding for research presented in a scientific article or scientific article itself}

The authors would like to acknowledge the financial support of the National Funds provided by FCTFoundation for Science and Technology to VALORIZA-Research Center for Endogenous Resource Valorization. Also, The authors would like to acknowledge the financial support by the European Regional Development Fund (FEDER in Spanish) and by the Board of Extremadura to the Research Group of Sustainable Development and Territorial Planning through the financial help of reference GR18052.

\section{Creative Commons Attribution \\ License 4.0 (Attribution 4.0 International, CC BY 4.0)}

This article is published under the terms of the Creative Commons Attribution License 4.0

https://creativecommons.org/licenses/by/4.0/deed.en _US

\section{References:}

[1] Partidário, M. \& Jesus, J. Avaliação do Impacte Ambiental. Caparica, 1994. Partidário, M. R., Jesus, J., (1994): “Avaliação do Impacte Ambiental", Centro de Estudos de Planeamento e Gestão do Ambiente. Costa da Caparica. 
[2] Partidário, M. R., Jesus, J., (2003): "Fundamentos de Avaliação de Impacte Ambiental", Universidade Aberta. Lisboa.

[3] Clark, B. (1993). Centre for Environmental Management and Planning. Aberdeen, 1993. Ed. Springer: ISBN 978-94-009-6381-8

[4] Castanho, R. A (2014). Assessment processes and monitoring of the environmental impact of a Golf Course - Basis for Definition of Monitoring and Mitigation Measures for the field "Guadiana Golf" in Badajoz, Spain. Master Thesis, ESAE - Instituto Politécnico de Portalegre, Portugal.

[5] Conelly, R. The UN Convention on EIA in a Transboundary Context: A historical perspective. Environmental Impact Assessment Review. Elsevier, 1999.

[6] Conelly, R. The UN Convention on EIA in a Transboundary Context: A historical perspective. Environmental Impact Assessment Review. Elsevier, 1999.

[7] Loures L, and Panagopoulos T. (2010). Reclamation of derelict industrial land in Portugal - greening is not enough. International Journal of Sustainable Development and Planning. 2010;5(4):343-350

[8] Viegas, A., Loures, L. \& Nunes, J. O Rural como Espaço de Produção e Sustentabilidade: Tecnologias, Agricultura e Ambiente. Elvas, 2013. ISBN: 978-989-98406-7-6. pp.245-267

[9] Naranjo Gómez, J.M., Cabezas Fernández, J., Castanho, R.A., and Pinto Gomes, C. (2021). Assessing the Existing Vegetation Around Abandoned Mining Areas With Potentially Toxic Heavy Metals: The Case of Extremadura Region. Chapter \#2 in the IGI GLOBAL Book: Management and Conservation of Mediterranean Environments ISBN13: 9781799873914. pp.1-13. DOI: $10.4018 / 978-1-$ 7998-7391-4.ch001.

[10] Castanho, R.A. and Martín Gallardo, J. (2021). Management and Conservation of
Mediterranean Environments - A Preface. Introductory Chapter in the IGI GLOBAL Book: Management and Conservation of Mediterranean Environments ISBN13: 9781799873914. pp.XV-Xviii. DOI: 10.4018/978-1-7998-7391-4.

[11] TECNINVEST. E.I.A. - Centro Integrado de Valorização e Tratamento de Resíduos Hospitalares e Industriais. Lisbon, 2011.

[12] TECNINVEST. Empreendimento Turístico em Diogo Martins - Campo de Golfe. Estudo de Imapcte Ambiental, Resumo Não Técnico. Lisbon, 2005.

[13] Kaletová, T., Loures, L., Castanho, R.A., Aydin, E., Gama, J., Loures, A., Truchy, A. (2019). Relevance of Intermittent Rivers and Streams in Agricultural Landscape and Their Impact on Provided Ecosystem Services-A Mediterranean Case Study. pp. 3-16. Int. J. Environ. Res. Public Health (IJEPRH) 2019, 16, 2693; doi:10.3390/ijerph16152693

[14] Raposo, M., Castanho, R., Meireles, C., Santos, P. and Pinto-Gomes, C. (2018). Border Effect on Flora and Raptors Diversity. An Iberian Case. Chapter in the Book: ORDENACIÓN DEL ESPACIO: CIUDADES INTELIGENTES, TURISMO Y LOGÍSTICA. Ed. Thomson Reuteurs Aranzadi. pp. 293-303 ISBN 978-84-1309-068-9.

[15] Kaletová, T., Loures, L. and Castanho, R. (2018). Proposal of Indicators of Ecosystem Services (ES) Provided by Agriculture and Intermittent Rivers and Ephemeral Streams (IRES), Case Study Caia River Basin, Portugal. Chapter in the Book: ORDENACIÓN DEL ESPACIO: CIUDADES INTELIGENTES, TURISMO Y LOGÍSTICA. Ed. Thomson Reuteurs Aranzadi. pp. 293-303 ISBN 978-841309-068-9.

[16] Raposo, M., Castanho, R.A., Machado, M., Castro, C., Santos, P. and Pinto-Gomes, C. (2018). The Relevance of Vegetation Series on the Maintenance and Sustainability of Public Spaces in the South-west Iberian Peninsula. 
Chapter in the Book: Landscape Architecture: The Sense of Places, Models and Applications. Ed. InTech. ISBN 978-1-78923-713-9. pp.254272.

[17] Loures, L. and Crawford, P., (2008). Democracy in progress: using public participation in post-industrial landscape (re)development. WSEAS Transactions on Environment and Development, Vol. 4(9) 794803.

[18] Kurowska-Pysz, J., Castanho, R. and Loures, L., (2018). Sustainable Planning of Cross-Border Cooperation: A Strategy for Alliances in Border Cities. Sustainability, 10 (5), pp 1-26. DOI: 10.3390 /su10051416.

[19] Loures, L. and Panagopoulos, T., (2010). Reclamation of derelict industrial land in Portugal - greening is not enough. International Journal of Sustainable Development \& Planning, Vol. 5(4) 343-350

[20] Nunes, J., Ramos-Miras, J., Lopez-Piñeiro, A., Loures, L., Gil, C., Coelho, J. and Loures, A., (2014). Concentrations of available heavy metals in Mediterranean agricultural soils and their relation with some soil selected properties: A case study in typical Mediterranean soils. Sustainability, 6 (12), pp. 9124-9138.

[21] Vargues, P. and Loures, L., 2008. Using Geographic Information Systems in Visual and Aesthetic Analysis: the case study of a golf course in Algarve. WSEAS Transactions on Environment and Development, Vol. 4(9) 774783.

[22] Mora Aliseda J., Garrido Velarde J., Bedón Garzó R. (2017). Indicators for sustainable management in the Yasuni national park. Wseas transactions on business and economics, Vol 14,

[23] Garrido Velarde J., Montero Parejo M.J., Hernández Blanco J., García Moruno L. (2017). Use of video and 3D scenario visualisation to rate vegetation screens for integrating buildings into the landscape. Sustainability, 9, 2017
[24] Garrido Velarde J., Montero Parejo M.J., Hernández Blanco J., García Moruno L. Visual analysis of the height ratio between building and background vegetation. Two rural cases of study: Spain and Sweden. Sustainability, 10, 2018

\section{Creative Commons Attribution License 4.0 (Attribution 4.0 International, CC BY 4.0)}

This article is published under the terms of the Creative Commons Attribution License 4.0

https://creativecommons.org/licenses/by/4.0/deed.en_US 